\title{
Vesicular virgular apparatus in the graptolite Orthograptus calcaratus
}

\author{
MERETE BJERRESKOV
}

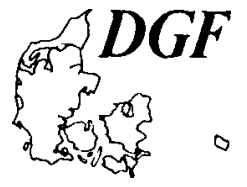

Bjerreskov, M.: Vesicular virgular apparatus in the graptolite Orthograptus calcaratus. Bull. geol. Soc. Denmark, vol. 35 pp. 115-124, Copenhagen, July 1st, 1987. https://doi.org/10.37570/bgsd-1986-35-12

A pyritized virgular apparatus (nematularium) has been observed in Orthograptus calcaratus s.l. (Lapworth) from the Pleurograptus linearis Zone in the Ordovician Dicellograptus Shale on Bornholm, Denmark. Specimens preserved in full relief show the free part of the nematularium to be circular in cross section, $0.5 \mathrm{~mm}$ in diameter, surrounded by a carbon film, and infilled with pyrite. The surface is covered by rounded elongated hummocks that generally are irregularly arranged but in a few cases lie in one row or are paired. SEM investigations of cross sections reveal that the nematularium has internal carbonized membranes surrounding vesicular tissue. These virgular structures form in the distal part of the thecae portion of the rhabdosome.

This new type of vesicular nematularium is unique as earlier observations on other diplograptids showed the nematularia to be single-walled, with two or three vanes. The formation of the vesicular virgular apparatus and its life function is discussed: it most likely had a floating and/or stabilizing function, and may have contained buoyant material, such as vacuolated tissue with fat globules or gas inclusions.

M. Bjerreskov, Institute of Historical Geology and Palaeontology, University of Copenhagen, Øster Voldgade 10, 1350 Copenhagen K, Denmark. April 19th, 1986.

Terminal modifications of the distally projecting nema (virgula) have been recorded in many different scandent graptolites, mainly within the Diplograptina. Some of the expanded nemal structures were considered to be possibly vesicular e.g. Hundt (1953), Bulman (1964 pars), Müller \& Schauer (1969) and Müller (1975), whereas others were recorded as two- or three-vaned structures (Bulman 1947, 1964, and Rickards, 1975). The three-vaned structures in Diplograptus penna Hopkinson, Cystograptus vesiculosus (Nicholson) and Pseudoclimacograptus scharenbergi (Lapworth) were described in detail by Jones \& Rickards (1967), Urbanek et al. (1982) and Mitchell \& Carle (1986) respectively.

Nemal discs in juvenile rhabdosomes were reported by Ruedemann (1897, 1904), who considered them to be attachment discs. Later, Finney (1979) and Finney \& Jacobsen (1985) described spherical nemal vesicles in immature rhabdosomes of Dicellograptus sp. and in mature specimens of Pseudoclimacograptus angulatus (Bulman), Climacograptus tubuliferus Lapworth and Glossograptus ciliatus Emmons. These bladderlike structures were interpreted as floats.

Nevertheless the majority of nemal modifications are too poorly preserved to reveal their true structure, and the question remains open as to whether they are two- or three-vaned, vesicular, or further elaborated. In this paper a part of this question is elucidated by new well preserved material of Orthograptus calcaratus s.l., which has demonstrated hitherto unknown structures of a virgula apparatus in diplograptids. The present specimens have projecting blistered nemata internally filled with pyrite, indicating that the original structure was vesicular.

\section{Material}

The investigated graptolites were collected by the author in 1984 in the Caradoc-Ashgill Dicellograptus Shale at the Vasagaard section in the rivulet Læså in the southern part of Bornholm, Denmark. The samples comprise 14 specimens of $O$. calcaratus s.l. preserved in low to nearly full relief with carbonised periderms infilled with pyrite and bearing three dimensional virgular projections. In addition, more than 100 specimens of $O$. calcaratus s.l. have been recorded that are preserved as totally flattened carbon films.

The material derives from the lowermost $40 \mathrm{~cm}$ of the $3 \mathrm{~m}$ thick Pleurograptus linearis Zone and 
one relief specimen was collected $100 \mathrm{~cm}$ above the base of the zone. All the graptolites have been found in dark grey shale.

Rhabdosome length in the present specimens of $O$. calcaratus s.l. reaches more than $8 \mathrm{~cm}$. Generally the width increases from $1.25-1.5 \mathrm{~mm}$ proximally to $2 \mathrm{~mm}$ at the level of th $5^{1}, 3.2 \mathrm{~mm}$ at th $10^{1}$ and the maximum distal width is $3.5 \mathrm{~mm}$. In some cases the distalmost width diminishes to 3 $\mathrm{mm}$. The thecae are of orthograptid type, having slightly introverted mucronate apertures with thickened rims. The thecae overlap for about half their length, are inclined at $30^{\circ}$ to the axis of the rhabdosome, and obtain a length of $2 \mathrm{~mm}$ distally. They number 6 in the most proximal $5 \mathrm{~mm}$, $10-11$ in the proximal $10 \mathrm{~mm}$, and distally $7.5-9$ per $10 \mathrm{~mm}$. The sicula is $1.5 \mathrm{~mm}$ long and has a $0.5 \mathrm{~mm}$ long virgella. Th1 $1^{1}$ and th $1^{2}$ have stout ventrally curved spines up to $0.95 \mathrm{~mm}$ long. In obverse view the median septum originates at the level of th $7^{1}$.

The specimens are similar to Orthograptus calcaratus robustus (Hadding). Hadding (1915) characterized this subspecies by a slower increase in width than in Orthograptus calcaratus calcaratus (Lapworth), and by a more slender rhabdosome than Orthograptus calcaratus basilicus (Lapworth). However, as remarked by Williams (1982), the whole $O$. calcaratus group is in need of revision (which is beyond the scope of this paper). The present specimens are merely referred to $O$. calcaratus s.l. $O$. calcaratus robustus was reported from the upper part of the clingani Zone by Hadding (1915) whereas the present specimens are from the lower part of the linearis Zone, from a level at which Hadding reported the presence of $O$. calcaratus basilicus.

All the figured specimens are deposited in the Geological Museum of the University of Copenhagen (MGUH).

\section{Description of nema}

The transformation from a simple thread-like prolongation of the nema (virgula) into a complex apparatus as described below is principally similar to other nemal elaborations. Such complicated nemal apparata were named nematularia by Müller (1975) and the virgular apparatus de- scribed below can also be designated as a nematularium.

In the present specimens, the free part of virgula can obtain a length of at least $4 \mathrm{~cm}$ distal to the thecate part of the rhabdosome. In full relief the nematularium is $0.5 \mathrm{~mm}$ wide and cylindrical (fig. 5): when preserved in low relief it is approximately elliptical in cross section (fig. 8). Under the light microscope the relief nematularium can be seen to be surrounded by a carbon film and filled with pyrite. The surface of the relief specimens is formed by irregularly arranged round to elongate hummocky structures, which can occur singly, paired or up to five across the nematularium (figs. 2,3). Apparently there are no morphological changes of the surface from the proximal to the distal end of the free nematularium.

In flattened adult specimens the width of the projecting nematularium varies from $0.75 \mathrm{~mm}$ to $1.25 \mathrm{~mm}$ and the nematularium appears generally as a threadlike band, parallel sided with a continuous and evenly carbonized periderm. There are no median grooves or ridges like those seen in flattened specimens of a three-vaned nematularium (fig. 1).

In mature specimens the bulbous nematularium extends proximally into the distal thecate part of the rhabdosome for up to $3 \mathrm{~cm}$. The width of the nematularium here is about $0.5 \mathrm{~mm}$ in low relief and $0.3 \mathrm{~mm}$ in full relief.

The intrarhabdosomal part of the nematularium can ony be recognised by the hummocky surface in specimens preserved in full relief. In flattened specimens the irregular surface disappears and only some vague median longitudinal ridges and grooves can be observed.

In immature specimens of $O$. calcaratus s.1. the nema is prolonged distally beyond the thecate part of the rhabdosome. As an example a $12 \mathrm{~mm}$ long rhabdosome has a thread $10 \mathrm{~mm}$ long and $0.2 \mathrm{~mm}$ wide. All the recorded juvenile specimens are flattened and no characteristic surface structure have been observed in the nemata, which all appear as smooth threads.

\section{Ultrastructures}

Fragments of both extrathecal and intrarhabdosomal parts of the nematularium were studied with a scanning electron microscope (SEM). 

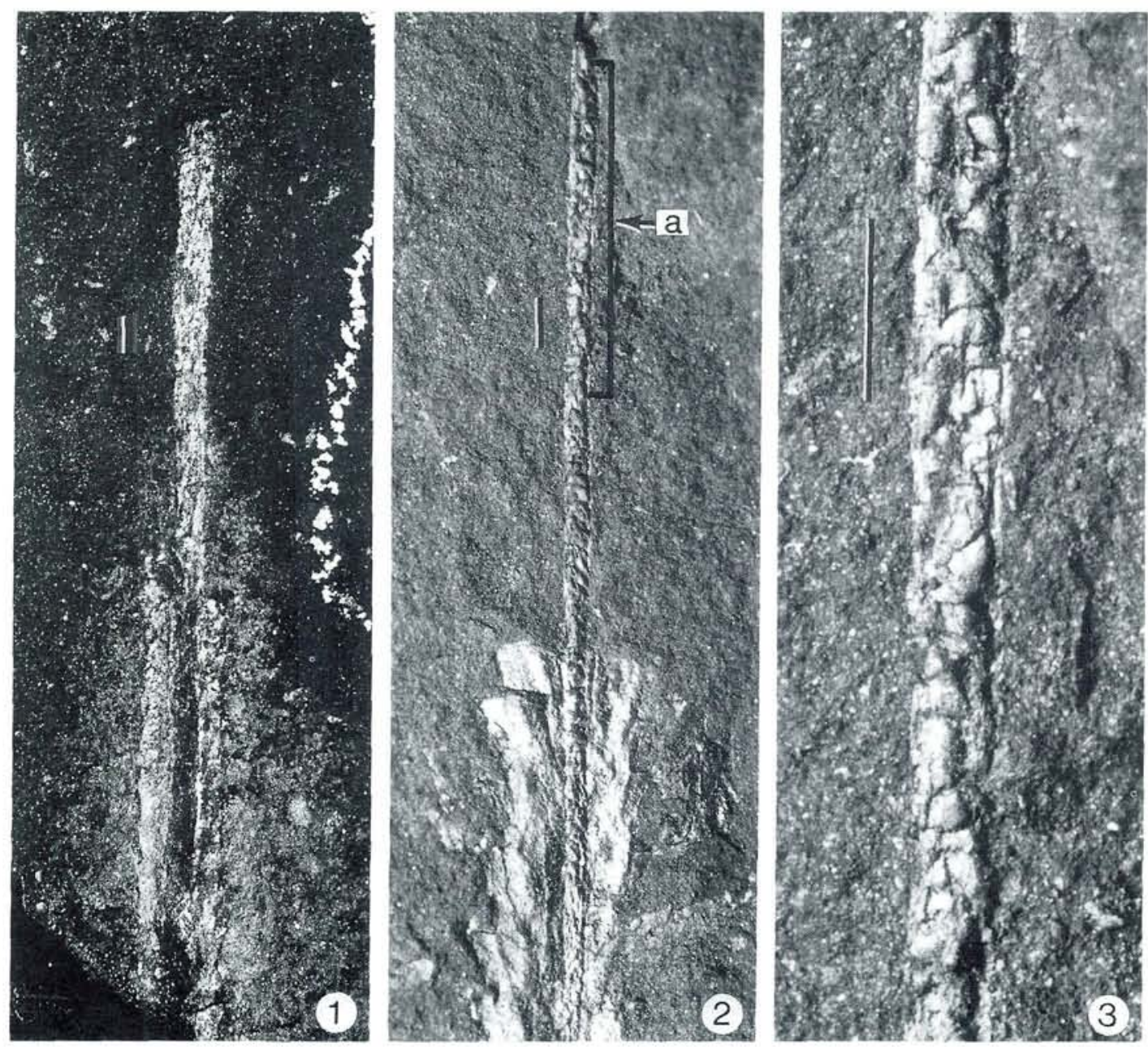

Fig. 1. Orthograptus calcaratus s.1. with flattened thecal portion and projecting nema, a = fig. 3 . MGUH $17064, \times 4$, bar scale $1 \mathrm{~mm}$.

Fig. 2. Orthograptus calcaratus s.l. Partly pyritized specimen showing nematularium in relief. The blistered free part of the nematularium continues proximally into the distal part of the thecate portion of the rhabdosome, $\mathrm{a}=$ Fig. 3. MGUH 17065, $\times 6$, bar scale I $\mathrm{mm}$.

Fig. 3. Enlargement of a part of the projecting nematularium in fig. 2, showing its irregular hummocky surface. $\times 24$, bar scale $1 \mathrm{~mm}$.

Fragments of the nematularium were placed on stubs and coated with gold.

The surface of the free part of the nematularium is covered by a carbon film, 3-5 $\mu \mathrm{m}$ thick, and much thinner than the normal carbonised periderm of the thecate part of pyritized graptolites (which is about $15 \mu \mathrm{m}$ thick e.g. Crowther, 1981, pl. 3). At high magnification, the nematularium shows a rather smooth and even periderm surface (fig. 4); the dark broken lines are regarded as secondary fractures.

In some specimens the outer periderm appears massive in cross section (figs. 9, 13), whereas other samples clearly show an outer laminated carbon film (fig. 15).

A cross section of the nematularium reveals that the uneven hummocky surface is due to structures that appear approximately ellipsoidal to sphere-like in full relief. Fig. 8 shows that a single hummock corresponds to a spherical to ellipsoidal structure that continues internally into the nematularium. The cross section shows at least five such structures that are clearly delimited from each other by cavities within the inter- 
nal pyrite mould. Some are apparently surrounded by thin membranes (fig. $9, \mathrm{c}$ ). In the flattened lateral rims the internal membranes continue around the deformed structures (figs. 8, b; 10). By breakage of the nematularium the spherical structures are revealed on fracture zones generally along the margins of the globules, where membranes are also observed. Fig. 6 illustrates that a break of one of the spheres has apparently left a rounded pit on the surface of the nematularium.

The transition of a distal fragment of a nematularium from full relief to a flattened state is shown in fig. 7. In relief, globules of varying size are present. At the transition into the flattened condition, the carbon layers are pressed together, leading to the disappearence of the hummocky surface and transformation into a laminated smooth carbon film.

The intrarhabdosomal part of the nematularium has also been investigated (figs. 11-15). Generally the internal part has a less pronounced hummocky surface than that found in the free part of the nematularium. This is most likely caused by the cover of the outer layer of the rhabdosomal periderm. In the figured specimen a ridge-like structure apparently passed into one of the globules (fig. 11).

The internal part of the intrarhabdosomal fragments is traversed by thin carbon films which merge with the outer periderm (figs. 10, 15) and become much thinner inside, about $1 \mu \mathrm{m}$ thick.
The internal structures are constructed of a delicate meshwork of membranes with rather smooth surfaces. The thin membranes surround minor internal vesicular structures (figs 13,14). These spherules are about $10 \mu \mathrm{m}$ in diameter.

After removal of the pyrite infillings, fragments of the extrathecal part of the nematularium were embedded in Epon 812 before thin sectioning. The samples were studied under a photo microscope. Fig. 16 shows a cross section of a nematularium.

The periderm of the nematularium has a massive structure with a rather smooth outer surface. The inner side bears rounded impressions, apparently separated by spinose projections (fig. $16, a)$. Within the nematularium, near the centre of the cross section, a massive carbon film is observed with the same rounded impressions as on the inner peridermal surface (fig. 16, b). This carbon film is either a part of an internal membrane that separates the larger blisters of the nematularium, see e.g. fig. 8 , or a piece of the outer membrane detached.

The internal tissue has a vesicular structur and is composed of thin, less massive carbon films with rounded vesicles (fig. 16, c). The structure is equivalent to that observed under the SEM (fig. 14). The internal carbonaceous tissue is connected with the inner surface of the massive outer periderm (fig. 16, d) through the spinose projections. This connection was also demonstrated by the SEM investigation (fig. 15).

Fig. 4. Surface of the carbonized periderm from a distal part of the pyritized nematularium of Orthograptus calcaratus s.1. in fig. 2. The surface has a smooth appearance, the dark broken lines are most likely secondary fractures. $14.000 \times$, bar scale $1 \mu \mathrm{m}$.

Fig. 5. Broken end of a free part of a pyritized nematularium from Orthograptus calcaratus s.l., showing the approximately cylindrical cross section and the infilling of pyrite. MGUH 17066, $\times 230$, bar scale, $100 \mu \mathrm{m}$.

Fig. 6. Fragment of a free distal part of a pyritized nematularium from Orthograptus calcaratus s.l. The specimen is composed of approximately globular structures with cavities (a) in between. A rounded pit on the surface most likely represents breakage of on of globules (b). MGUH 17065, x 140, bar scale $100 \mu \mathrm{m}$.

Fig. 7. Fragment of a free part of a nematularium of Orthograptus calcaratus s.l. showing the transition from relief to flattened preservation. $\mathbf{a}=$ part in relief composed of minor blisters. $b=$ flattened part where the blistered structures have disappeared, and the surrounding carbon membranes are pressed together into a laminated carbon film. MGUH 17067, $\times 70$, bar scale $100 \mu \mathrm{m}$.

Fig. 8. Cross section of the extrathecal part of the pyritized nematularium of Orthograptus calcaratus s.1. fig. 2. The internal part is composed of spheres, each corresponding to an outer hummock on the surface. The spheres are separated by internal membranes and cavities (c). $d=$ lateral part with a flattened hollow structure surrounded by carbon membranes, box $a=$ fig. 9 , box $b=$ fig. 10 , $\times 135$, bar scale $100 \mu \mathrm{m}$.

Fig. 9. Enlargement of the mesial part, box a, of fig. 8. One of the blisters has an approximately triangular cross section. a = periderm, $b=$ thickened part of the periderm, showing massive structure. $c=$ thin membrane separating two blisters. $\times 490$, bar scale $10 \mu \mathrm{m}$. 

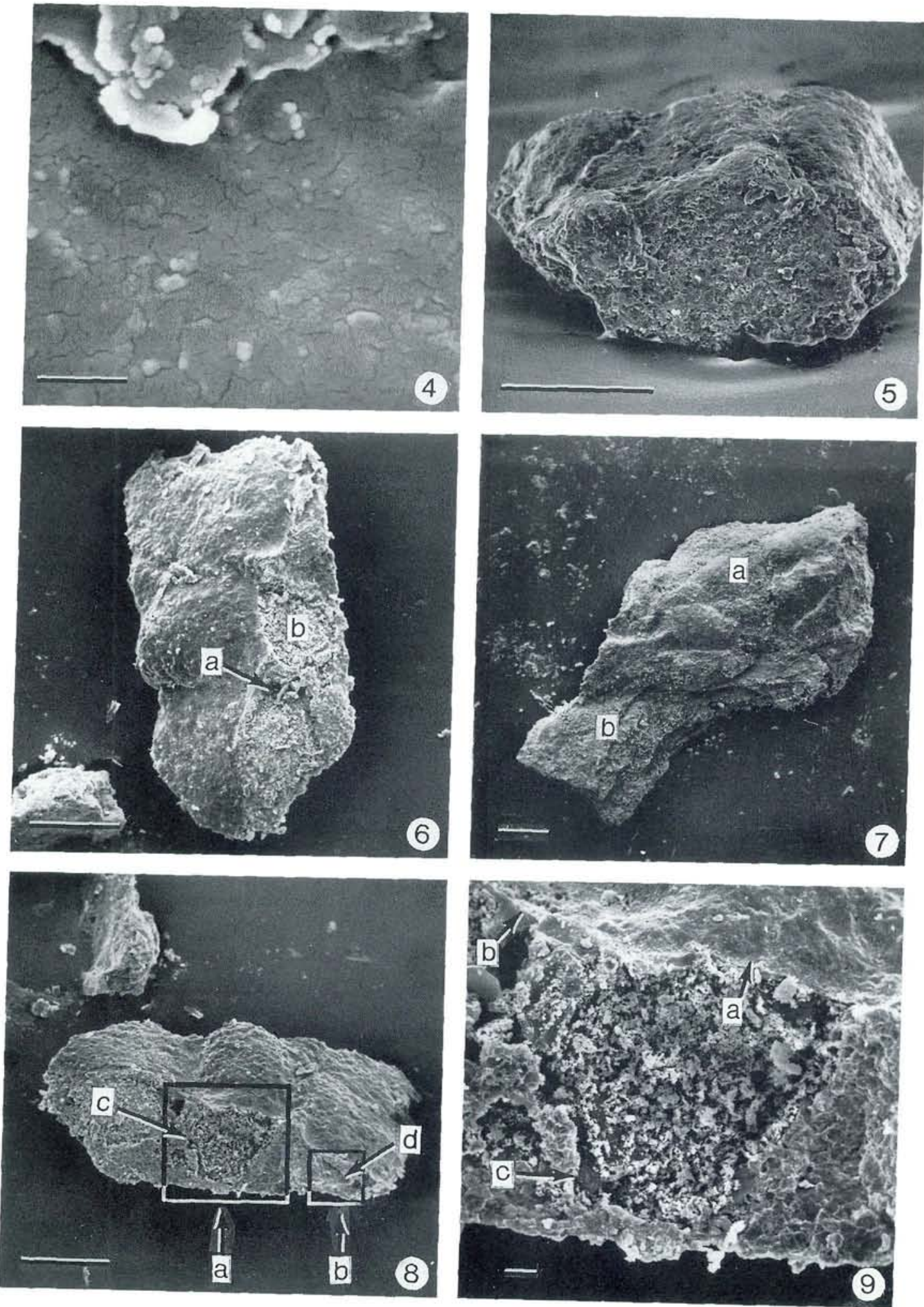


\section{Discussion and conclusion}

In conclusion, the ultrastructural (SEM) investigations have shown that the nematularium of $O$. calcaratus s.l. is composed of larger spheroidal structures of varying sizes. The spheroids are separated from each other by thin transverse carbonized membranes, and are infilled by vesicular tissue. These structures have not been described before in graptolites. The nature of the vesicular tissue has not been demonstrated. It may be fusellar fabric, now degraded and deformed by the pyrite infillings. However, further investigations are needed before any final conclusions may be drawn on the detailed ultrastructural composition of the periderm and the internal tissue of the present nematularia.

The vesicular structures described above are apparently a very rare modification of the nema. Reinvestigation of all the Ordovician and Silurian diplograptids bearing prolonged nemata housed in the Geological Institute in Copenhagen, as well as of the original Dicellograptus Shale material of Hadding in the Geological Institute of Lund, Sweden, has not revealed any similar structures. Study of the literature revealed only one paper (Müller \& Schauer, 1969, fig. 8d), that indicated a somewhat similar structure of a nematularium, illustrated but not described. In that paper a specimen of "Petalolithus" sp. was figured and classified as having the vinculare type of nema, in which the nema is divided into two branches, separated by carbonized periderm, and locally twisted. These modifications were observed particularly in representatives of Petalograptus. Müller \& Schauer (1969) and Müller (1975) suggested that there might have been a relatively flat gas filled chamber between two carbon films. Müller \& Schauer's (1969 fig. 8d) specimen of "Petalolithus" sp. apparently has the same bulbous structures as the material from Bornholm in the proximal part of the projecting nema, and maybe also along the proximal margins of the nemal division into the two branches. However, the specimen has not been seen by the present author, and the drawing can only tentatively be said to illustrate a vesicular structure similar to that described here.

\section{Mode of formation of the nematularium}

Aspects of the mode of formation of virgular apparata were thoroughly discussed by Urbanek et al. (1982) and Mitchell \& Carle (1986) on the basis of the three-vaned nematularia of Cystograptus vesiculosus and Pseudoclimacograptus scharenbergi respectively. Only a few remarks are added here on the formation of the present vesicular structure.

In accordance with the fully pterobranchian way of skeletal growth, as carried out by mobile zooids (e.g. Andres 1980) the individuals would have had to secrete complicated, delicate vesicular structures at up to $4 \mathrm{~cm}$ from the distal thecae. This appears to be even more questionable than the formation of the simpler, three-vaned structures described by Urbanek et al. (1982) and Mitchell \& Carle (1986).

As an alternative to the pterobranchian mode

Fig. 10. Enlargement of the right lateral part, $b o x b$, in fig. $8, a=$ outer periderm, $b=$ internal membrane fusing into the outer periderm. $c=$ chalcopyrite altered to bornite. $\times 1105$, bar scale $10 \mu \mathrm{m}$.

Fig. 11. Intrathecal part of Orthograptus calcaratus $\mathrm{s} .1 . \mathrm{a}=$ fragment of theca, $\mathrm{b}=$ nematularium. $\mathrm{c}=$ ridge-like structure passing into one of the globules. MGUH $17068, \times 35$, bar scale $100 \mu \mathrm{m}$.

Fig. 12. Cross section of the distal end of fig. 11. $a=$ thecae, $b=$ nematularium, box $c=$ fig. 13 , box $d=$ fig. $15 \times 60$, bar scale 100 $\mu \mathrm{m}$.

Fig. 13. Enlargement of the left upper part of the nematularium, box $\mathrm{c}$ in fig. 12. $\mathrm{a}=$ fragments of the outer rhabdosomal periderm. $\mathrm{b}=$ periderm of the nematularium with massive structure. box $\mathrm{c}=$ internal membrane forming a minor vesicle (see fig. 14 ). $\times 785$, bar scale $10 \mu \mathrm{m}$.

Fig. 14. Enlargement of box $\mathrm{c}$ in fig. 13, showing internal small vesicle. $\times 3990$, bar scale $1 \mu \mathrm{m}$.

Fig. 15. Enlargement of fig. 12, the lower part of the nematularium, box d. Here the outer periderm (a) is laminated and appears to continue into the internal part of the nematularium. $\times 1575$, bar scale $10 \mu \mathrm{m}$. 

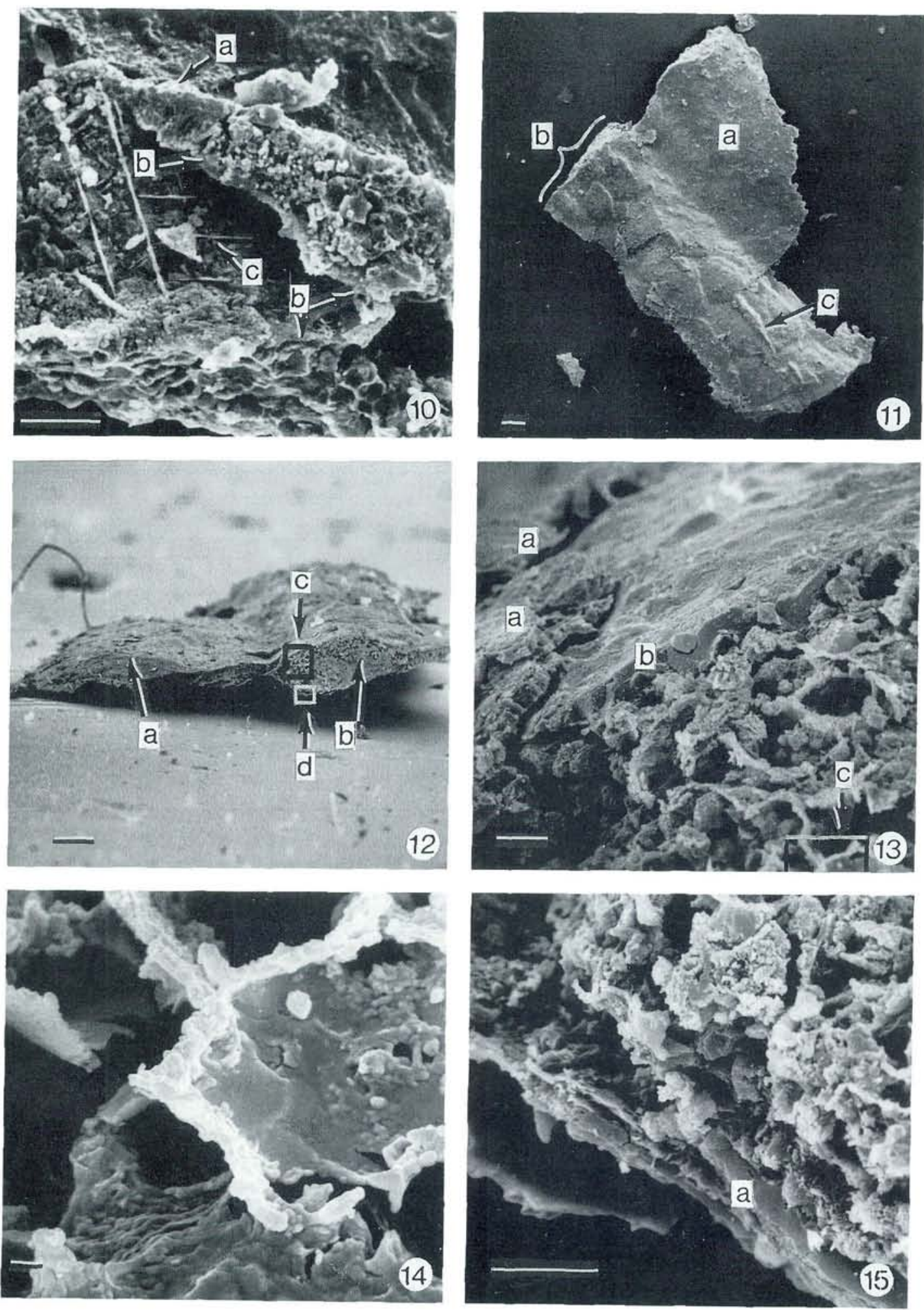


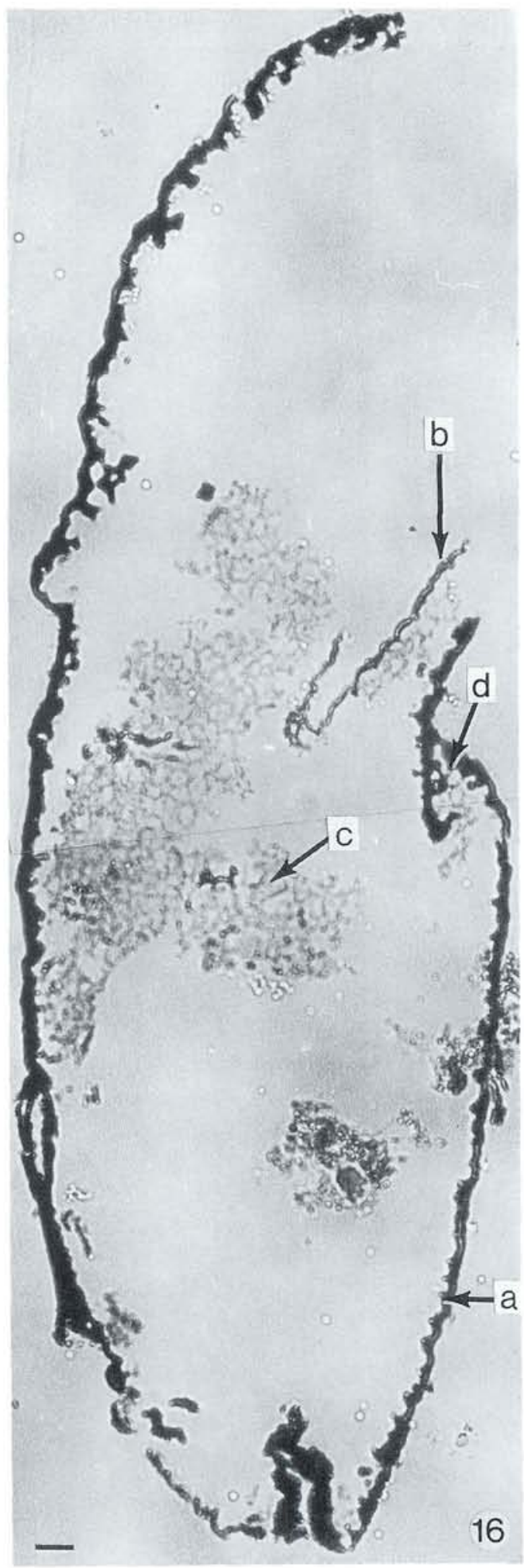

Fig. 16. Light micrograph of a transverse section through the extrathecal part of the nematularium of $O$. calcaratus s.I. a = outer periderm, $\mathrm{b}=$ outer periderm or transverse membrane, $\mathrm{c}=$ inner carbonaceous reticulate tissue, $\mathrm{d}=$ connection between the inner tissue and the outer periderm, MGUH 17069 , $\times 470$, bar scale $10 \mu \mathrm{m}$.

of skeleton building, an epithelian mode of formation for the present nematularium may be considered. In this connection there is a principle difference between the structures in the nema of e.g. C. vesiculosus and O. calcaratus s.l. The former is a single-walled structure, built by microfusellar tissue and having no space for internal secretion (Urbanek et al., 1982). The nema in $O$. calcaratus s.l. has a hollow structure composed of internal membranes, having minor vesicles. Here, both external and internal epithelia may have operated in the formation of the nematularia. Internal secretion has recently been suggested by Mitchell and Carle (1986) for the threevaned nematularium of $P$. scharenbergi. However, until additional ultrastructural investigations of the present material have been carried out, no further conclusions about the formation of the present vesicular nematularium can be drawn.

\section{Function of the nematularium}

It is more than 100 years since Hall (1865) suggested that the graptolites were planktic. Subsequently, theories of their mode of life have been discussed from many points of view. The theory that graptolites floated attached to seaweed (Lapworth 1897) has been replaced by suggestions of passive drift with vacuolated tissue or spiral rotation (Bulman, 1964, 1970; Rickards, 1975) or by floatation devices such as hollow spheres (Finney, 1979 and Finney \& Jacobson, 1985). In opposition to the passive drift theory, Kirk (e.g. 1969, 1972), and Bates \& Kirk (1984) suggested that graptolites were automobile through their ciliary generated feeding currents. The many aspects of the function of "floats", and especially of the three-vaned nematularia were thoroughly discussed by Urbanek et al. (1982) and Mitchell \& Carle (1986).

The vesicular nemal structure suggests that the nematularium may have housed buoyant material 
and may thus have functioned as a float and/or stabilising organ, maybe even having the ability of regulation of weight. The material within the vesicles may have been tissue containing inclusions of either gas, fat droplets or fluids for substitution of low density salts. Firm evidence of the nature of the contents, however, is lacking.

By reducing the weight of the colony, the supposed float structures might have helped any automobility created by feeding currents as suggested by Kirk (e.g. 1969) and Bates \& Kirk (1984). However, if the vesicular virgular apparatus acted as a weight regulator, ciliary generated feeding currents might not have been necessary at all to assure a stable buoyant existence; even diurnal vertical migrations might have been possible for members of the $O$. calcaratus group and other diplograptids with similar nemal structures.

Acknowledgements. Piotr Mierzejewski, Warszawa is thanked for valuable discussions and for preparing specimens for ultrathin sections. Thanks are due to J. Fuglsang Nielsen for taking the SEM pictures, J. Aagaard for the photographic work, and R. Bromley for improving the English of the manuscripts.

\section{Dansk sammendrag}

I pyritiserede eksemplarer af Orthograptus calcaratus s.l. (Lapworth) fra Pleurograptus linearis Zonen i Dicellograptus Skiferen på Bornholm er der fundet en elaboreret nema (= virgula i diplograptider), som viser en hidtil ukendt struktur. I eksemplarer med fuldt relief er den frie del af virgula tilnærmelsesvis cylinderformet, $0,5 \mathrm{~mm}$ i diameter. Den består yderst at en forkullet periderm, og er indvendig udfyldt af pyrit. Overfladen af virgula er ujzvn med runde til ovale forhøjninger, som generelt er uregelmassigt placeret, men kan forekomme enkeltvis i rakke eller være parvis placeret langs virgula.

Ultrastrukturundersøgelser af tværsnit af virgula viser, at der til hver forhøjning på overfladen svarer en mere eller mindre globular indre struktur, som er omgivet af en kulhinde tyndere end peridermen. Endvidere er de enkelte globulære strukturer opbygget af et netvark af membraner, som omgiver små hulheder, ca. 10 my i diameter. Modificeringen af virgula til denne blærede struktur finder sted i den distale del af den thecate del af rhabdosomet, idet den ujævne overflade er iagttaget i op til 3 $\mathrm{cm}$ ned $\mathrm{i}$ rhabdosomet målt fra det distale thekepar. I eksemplarer af $O$. calcaratus bevaret i fladtrykt tilstand fremtræder den frie del af virgula som en tråd blot bestående af en glat kulhinde.

En cylinderformet nema med en indvendig blæret struktur er ikke før iagttaget hos graptoliter. Tidligere undersøgelser af kompliceret byggede nemata (= nematularia) bevaret $\mathrm{i}$ relief har vist en opbygning bestående af 2 eller 3 kompakte mvinger «, som danner $180^{\circ}$, henholdsvis $120^{\circ}$, med hinanden. Dannelsen og funktionen af den vesikulære virgula er kort diskuteret. Sandsynligvis havde de hule nematularia en stabiliserende og/ eller vægtregulerende funktion ved graptoliternes pelagiske levevis $i$ havet. De indre hulheder $i$ virgula kan have rummet inklusioner med lavere vægtfylde end havvand - måske bestående af gasart(er) eller af fedtdråber - med det formål at bibringe graptolitkolonien den rette position $\mathbf{i}$ vandet.

\section{References}

Andres, D. 1980: Feinstrukturen und Verwandschaftsbeziehungen der Graptolithen. Paläont. Z. 54, 129-170.

Bates, D. E. B. \& Kirk, N. H. 1984: Autecology of Silurian graptoloids. Spec. Pap. Palaeont. 32, 121-139.

Bulman, O. M. B. 1947: Monograph of the Caradoc (Balclatchie) graptolites from the limestones in Laggan Burn, Ayrshire. 3. Palaeontograph. Soc. Lond., Mon., 59-78.

Bulman, O. M. B. 1964: Lower Palaeozoic plankton. Q. J. Geol. Soc. Lond. 120, 455-476.

Bulman, O. M. B. 1970: Graptolithina. In Teichert C. (ed.): Treatise on Invertebrate Paleontology V, 1-163, $2^{\text {nd }}$ ed., New York, N.Y. Lawrence, Kansas.

Crowther, P. R. 1981: The fine structure of graptolite periderm. Spec. Pap. Palaeont. 26, 119 pp.

Finney, S. C. \& Jacobson, S. R. 1985: Flotation devices in planktic graptolites. Lethaia 18, 349-359. ogy $5,31-39$.

Finney, S. C. \& Jacobson, S. R. 1985: Flotation devices in planktic graptolites. Lethaia 18, 349-359.

Hadding, A. 1915: Der mittlere Dicellograptus-Schifer auf Bornholm. Lunds Univ. Arsskr. Afd. 2, 11, 40 pp.

Hall, J. 1865: Graptolites of the Quebec Group. Geol. Surv. Canada, Canad. Organic Remains, dec. 2: 1-151.

Hundt, R. 1953: Graptolithen. Neue Erkenntnisse über die Leitversteinerungen der Silurformation. Neue Brehm-Bücherei $102,48 \mathrm{pp}$.

Jones, W. D. \& Rickards, R. B. 1967: Diplograptus penna Hopkinson, 1869, and its bearing on vesicular structure. Paläont. Z. 41, 119-131.

Kirk, N. 1969: Some thoughts on the ecology, mode of life, and evolution of the Graptolithina. Proc. Geol. Soc. Lond. 1659, 273-292.

Kirk, N. 1972: More thoughts on the automobility of graptolites. J. Geol. Soc. 128, 127-133.

Lapworth, C. 1897: Die Lebensweise der Graptolithen. In Walther, J. (ed.): Lebensweise fossiler Meeresthiere. Z. Deut. Geol. Gesell. 49, 238-258.

Mitchell, C. E. \& Carle, K. J. 1986: The nematularium of Pseudoclimacograptus scharenbergi (Lapworth) and its secretion. Palaeontology 29, 373-390.

Müller, A. H. 1975: Über das tierische Grossplankton (Graptoloidea) der silurischen Meere mit einigen allgemeinen Angaben über Graptolithina (Hemichordata). Biol. Rdsch. $13,325-344$.

Müller, A. H. \& Schauer, M. 1969: Über Schwebeenrichtungen bei Diplograptidae (Graptolithina) aus dem Silur. Freiberger Forsch. - H. C. 245, 5-26.

Rickards, R. B. 1975: Palaeoecology of the Graptolithina, an extinct class of the phylum Hemichordata. Biol. Rev. 50 , $397-436$.

Ruedemann, 1897: Development and mode of growth of $\mathrm{Di}$ plograptus McCoy. New York State Geological Survey, Annual Report for 1894, 219-249.

Ruedemann, R. 1904: Graptolites of New York, Part I. New York State Museum Memoir 7, 457-803.

Urbanek, Koren', T. \& Mierzejewski, P. 1982: The fine structure of the virgular apparatus in Cystograptus vesiculosus. Lethaia 15, 207-228.

Williams, S. H. 1982: Upper Ordovician graptolites from the top Lower Hartfell Shale Formation. (D. clingani and $P$. linearis zones) near Moffat, southern Scotland. Trans. Soc. R. Edinburgh. Earth Sciences 72, 229-255. 